\title{
Isolation of N- Methyl Formamide from Red Algae Portieria hornemannii (Lyngbye) P.Silva Active against Two Plant Pathogenic Bacteria
}

\author{
S.R.Sivakumar ${ }^{1}$, S.Radhakrishan ${ }^{2}$, K.Kulangiappar ${ }^{3}$ \\ ${ }^{1}$ Department of Botany, Government Arts College, Ariyalur, 621713, Tamilnadu, India. \\ ${ }^{2}$ Senior Principal Scientist, Central Instrumentation Facility, Central Electro \\ Chemical Research Institute, Karaikudi- 630006, Tamilnadu, India. \\ Analytical CSIR-Central Electrochemical Research Institute, Karaikudi - 630003.Tamilnadu, India. \\ ${ }^{3}$ Electro Organic CSIR-Central Electrochemical Research Institute, Karaikudi - 630003. \\ Tamilnadu, India.
}

\begin{abstract}
In the present investigation, a purified compound exhibiting antibacterial activity isolated in 1:1 $(v / v)$ chloroform: methanol of red alga Portieria hornemannii collected along the coast of Pamban, Rameshwaram (Gulf of Mannar), Tamilnadu, India during Feburary 2007 was identified based on the HPLC,IR, NMR(1H \&13C) spectral data. This compound is colorless crystalline nature and yield of purified compound was $53.3 \mathrm{mg}-1 \mathrm{Kg}$ shade dried alga $0.00533 \%$ dry alga. The purified compound of $50 \mu \mathrm{g}$ showed $14.3 \pm 0.56 \mathrm{~mm}$ and $15.5 \pm 0.25 \mathrm{~mm}$ diameter zone of inhibition, whereas $100 \mu \mathrm{g}$ of commercial antibiotic Streptomycin sulphate showed $37.6 \pm 0.56 \mathrm{~mm}$ diameter zone of inhibiton against the test bacterium Xanthomonas axonopodies $p v$ citri and Xanthomonas carnpestris pv malvacearum through agar diffusion technique.
\end{abstract}

Keywords: Seaweed- Portieria hornemannii, N-methylformamide isolation, Spectral data, antibacterial activity against plant pathogens.

\section{INTRODUCTION}

Xanthomonas is a genus that includes numerous phytopathogenic species, characterized by a narrow range of hosts. However, members of this genus are able to infect a wide variety of plants, distributed among the monocotyledonous and dicotyledonous plant species of worldwide.Angular leaf spot caused by Xanthomonas axonopodis pv. malvacearum (Xam) [Sin. X. campestris pv.malvacearum (Smith) Dye)] is one of the most important diseases of tetraploid cotton (Gossypium hirsutum L. and G.barbadense L.) in many countries, including Brazil. The disease can cause heavy yield losses depending on the year and the cultivar. Vehicle of Xam and a source of primary inoculums Cotton seed are considered to be an important severe losses in commercial cotton fields in India, Brazil, Sudan and in the USA.

Citrus canker is a contagious disease of citrus (and some other plant species of the Rutaceae family) caused by the bacteria Xanthomonas axonopodis pathovar citri. Infected trees display unsightly lesions which can form on leaves, fruit and stems. Trees infected with the disease may suffer from low vigour and a reduction in fruit quality and quantity. Citrus canker is a serious disease impacting on citrus production in India,Pakistan,SriLanka,Brazil, USA, and is the subject of a number of control and eradication programs around the world. Experiences with this disease in other countries suggest that yield losses will range from five to 30 percent, depending upon the scion (variety).

Intensive application of synthetic pesticides in agriculture caused damage to the ecological state of the agricultural system (Abetz and young 1983) whereas, pesticides of biological origin are less toxic, generally affect only the target pest and closely related organisms, effective in very small quantities and decompose quickly, thereby resulting in lower exposures and largely avoiding the pollution problems caused by conventional pesticides. Though literature speaks diverse studies of bioactivity of seaweeds, works on testing the antibacterial efficacy of seaweeds against plant pathogens are comparatively a new concept and not much attempt have been made earlier in this line (Kulik,1995;Ara et al;1998,1999,2002ab, Arunkumar et al;2005;Kkumar et al;2008). Compared to 
the search for new pharmaceutical compounds, very little effort has been devoted to the exploration of agrochemical compounds from marine natural products (Fenical, 1997).Hence in the present invitro study we used two Plant Pathogens against isolated N-Methyl formamide from the red algae Portieria hornemannii as biocontrol.

\section{MATERIALS AND MethodS}

\subsection{Isolation of Plant Pathogenic Bacteria}

2.1.1.Xanthomnas axonopodis pv. citri (Hasse) Vauterin et al.(syn. X. citri pv. citri Gabriel et al., 1989):

The X. axonopodis pv. citri causing the disease called citrus canker on leaf and fruit of citrus. The infected leaf showing canker spot collected from the field using clean polythene bag brought to the laboratory. The leaf was surface sterilized using $0.1 \% \mathrm{HgCl}_{2}$ for $1 \mathrm{~min}$. and washed with sterilized distilled $\mathrm{H}_{2} \mathrm{O}$ at least thrice. Then the leaf was cut into small pieces and soaked in $5 \mathrm{ml}$ of sterilized distilled $\mathrm{H}_{2} \mathrm{O}$ for $12 \mathrm{hrs}$ for exudation of bacterium. The bacterial exudates were streaked on peptonesucrose agar (PSA) medium using the inoculation loop and incubated at $28^{\circ} \mathrm{C}$. Composition of PSA medium (Jin et al., 2001)Peptone - $5.0 \mathrm{~g}, \mathrm{Na}_{2} \mathrm{HPO}_{4} .12 \mathrm{H}_{2} \mathrm{O}-2.0 \mathrm{~g}, \mathrm{Ca}\left(\mathrm{NO}_{3}\right)_{2} .4 \mathrm{H}_{2} \mathrm{O}-0.5 \mathrm{~g}$,Sucrose- 15 g,Agar- 20 g,Distilled $\mathrm{H}_{2} \mathrm{O}-$ 1litre,pH- 6.8.

\subsubsection{Xanthomonas campestris pv. malvacearum (Smith 1901) Dye $1978 b$}

The $X . c$. pv. malvacearum causing angular spot disease (pink color in appearance) on the leaf and balls of cotton. The infected leaf showing the symptom collected from the field using clean polythene bag was brought to the laboratory. The leaf was surface sterilized using $0.1 \% \mathrm{HgCl}_{2}$ for 1 min. Then the leaf was cut into small pieces and soaked in $5 \mathrm{ml}$ sterile distilled $\mathrm{H}_{2} \mathrm{O}$ for $12 \mathrm{~h}$ for bacterial exudation. The bacterial exudates were streaked on Yeast Peptone Sucrose Agar (YPSA) medium and incubated at $28^{\circ} \mathrm{C}$.Composition of YPSA medium (Schaad et al,1988), Yeast extract- 5g,Peptone10g,Sucrose- 20g,Agar- 20g,Distilled $\mathrm{H}_{2} 0$ - 1 liter,pH- 7.4.

Colonies of both bacteria appeared on the media were subsequently sub-cultured to isolate pure single colony. Observations were made at every $12 \mathrm{~h}$ for 3 days. Pure bacterial colonies were transferred to slants containing its specific media and incubated at $28{ }^{\circ} \mathrm{C}$ for $48 \mathrm{~h}$ and stored at $4 \mathrm{C}^{\circ} \mathrm{C}$ until further work.

\subsection{Pathogenicity Test}

The final step in the identification of a bacterial plant pathogen was the pathogenicity test. In this step, the isolated bacteria were put back into the host plant to check if it is pathogenic and produces symptoms identical to the ones observed in the original diseased plant sample. To carry out the pathogenicity test, susceptible seedlings of three months old citrus and one month old cotton were raised in pots with garden soil, sand and farmyard manure with the ratio of $3: 1: 1 \mathrm{v} / \mathrm{v} / \mathrm{v}$ in botanical garden. Both the plant pathogens Xanthomonas axonopodis pv. citri and Xanthomonas campestris pv.malvacearum causing canker in citrus and angular spot in cotton, respectively identified based on colony morphology, Gram's staining and biochemical characteristics isolated from the diseased parts of the host plants were grown on their specific medium at $28{ }_{7}^{\circ} \mathrm{C}$ for $48 \mathrm{~h}$ harvested, re-suspended in sterilized distilled $\mathrm{H}_{2} \mathrm{O}$ and adjusted to 0.3 O.D at 460nm (10 $-10 \mathrm{cfu} / \mathrm{ml}$ bacterial cell concentration) using spectrophotometer. An aliquot of $3 \mathrm{ml}$ of the each bacterial suspension was inoculated by spraying on the adaxial side of punctured first three innermost leaves of citrus as well as cotton with their respective pathogenic bacteria with 3 replications. Sterilized distilled $\mathrm{H}_{2} \mathrm{O}$ was also inoculated as negative control for each plant. Development of symptoms as a result of infection was observed in every week till the appearance of typical disease. From the infected parts of citrus and cotton, pathogenic bacteria were re-isolated using PSA medium and confirmed as Xanthomonas axonopodis pv. citri and Xanthomonas campestris pv.malvacearum, respectively were cultured and maintained at $28^{\circ} \mathrm{C}$ until further work. Virulence of both the bacteria was maintained by infecting with their respective host on every 6 months and re-isolated from them.

Antibacterial assay through agar diffusion technique. (Arunkumar and Rengasamy, 2000a).

The antibacterial assay was carried out using the agar diffusion technique with $5.0 \mathrm{~mm}$ diameter Whatman \#1 paper discs. The assay was carried out on $1.5 \%$ nutrient agar medium.Composition of 

against Two Plant Pathogenic Bacteria

nutrient agar medium:Peptone- $10 \mathrm{~g}$,Beef extract $\quad-10 \mathrm{~g}, \mathrm{Na} \mathrm{Cl}-5 \mathrm{~g}$,Distilled $\mathrm{H}_{2} \mathrm{O}-1000 \mathrm{ml}$,agar powder $-15 \mathrm{~g}, \mathrm{pH}-7.0$.

Sterile paper discs loaded with $50 \mu \mathrm{l}(100 \mu \mathrm{g}$ of the substances) of different crude extracts using micropipettes were allowed to dry thoroughly under aseptic condition. Then the discs were impregnated in petri plates of $100 \mathrm{~mm}$ diameter containing ca. $20 \mathrm{ml}$ of nutrient agar medium smeared with $0.05 \mathrm{ml}$ of bacterial culture in exponential phase of $1.0 \mathrm{OD}$ at $590 \mathrm{~nm}$ and incubated at $28{ }^{\circ} \mathrm{C}$ for $48 \mathrm{~h}$. The diameters of the agar clear zones of bacterial inhibition around the disc as a result of diffusion of active substances were measured including disc as $\mathrm{mm}$ dia. and recorded for antibacterial activity. For the antibacterial assay, three replicates were maintained for each experiment and mean values expressed. The solvents used for reconstituting the crude extracts loaded on paper discs were treated as control and did not show any inhibition zone. The bioassay for each crude extracts was also conducted in nutrient broth for confirmation and the results were expressed. Antibacterial assay through agar diffusion technique: (Arunkumar and Rengasamy, 2000a)

The antibacterial assay was carried out using agar diffusion technique with $5.0 \mathrm{~mm}$ diameter Whatmann \# 1 paper discs. The assay was carried out on $1.5 \%$ nutrient agar medium. Peptone- 10g, beef extract- $10 \mathrm{~g}, \mathrm{NaCl}-5 \mathrm{~g}$, distilled $\mathrm{H}_{2} \mathrm{O}-100 \mathrm{ml}$, agar powder $-15 \mathrm{~g}$, $\mathrm{pH}-7.0$

Sterile paper discs loaded with $50 \mu \mathrm{l}(100 \mu \mathrm{g}$ of the substance) of extracts using micropipettes were allowed to dry thoroughly under aseptic condition. Then the discs were impregnated in petriplates of $10 \mathrm{~mm}$ diameter containing calcium $20 \mathrm{ml}$ of nutrient agar medium smeared with $0.05 \mathrm{ml}$ of bacterial culture in exponential phase of $10 \mathrm{OD}$ at $590 \mathrm{~nm}$ and incubated at $28^{\circ} \mathrm{c}$ for $48 \mathrm{~h}$. The diameter of the agar clear zones of bacterial inhibition around the disc as a result of diffusion of active substance were measured including disc as $\mathrm{mm}$ dia and recorded for antibacterial activity. For the antibacterial assay, three replicates were maintained for each experimental and mean values expressed. The solvents used for reconstituting the extracts loaded on paper discs were treated as control and did not show any inhibition zone.

Isolating and characterization of N-methyl formamide from red alga Portieria hornemanii.

\subsection{Extraction}

About $4 \mathrm{Kg}$ of live, healthy and disease free specimens of red alga Portieria hornemannii found along the coast of Pamban, Rameshwaram (Gulf of Mannar), Tamilnadu, India was collected during February 2007. After cleaning extraneous particles, seaweeds sample was cleanly washed with sterilized tap water for 3 times. Then the specimen was air dried under shade for 3 days. Shade dried sample was pulverized and ground as fire powder. The powered $300 \mathrm{~g}$ of algal sample was extracted with 700ml chloroform: methanol 1:1 (v/v) in air tight in 1 liter Erlenmeyer conical flask at room temperature in dark for 1 month. Extract was transferred to $500 \mathrm{ml}$ open conical flask and filtered using Whatmann no.1 filter paper. Then to the filtrate extract anhydrous MgSo4 was added and shook well in the separating funnel. The extract was kept for 1-2 months under dark condition without any disturbance in the $500 \mathrm{ml}$ beaker covered with aluminum foil.

After one month, colorless crystals started forming in the bottom of the flask leaving thick brownish liquid layer on the top. Observation on the day's progress noted increasing the number and size of the crystals settled at the bottom.

After 2 months upper liquid layer was decanted and the white crystal stored at 0oc. Sixteen mg of white crystals were obtained and stored in desiccates in the laboratory at room temperature. Antibacterial activity of crystal compound.

A crystal weighing 1mg dissolved in methanol was used for bioassay by agar diffusion technique.

The efficacy of pure compound isolated from the red alga Portieria hornemannii was compared with the commercial antibiotics used to control the two bacterial pathogen using agar diffusion technique

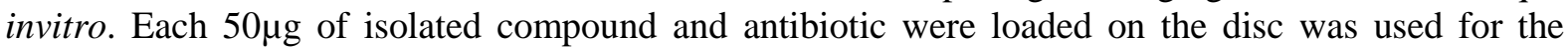
study.

\subsection{Chemical Characterization}

The crystal compound was subjected to several studies in order to characterize the chemical nature. The color of the compound was recorded. The purity of the compound was checked by analytical 
HPLC using shimadzo machine (Japan), column:ODS-18column $(125 \mathrm{~mm} \times 4.5 \mathrm{~mm})$ as the stationary phase. The element consists of methanol: water $(80: 20 \mathrm{v} / \mathrm{v})$ at a rate of $1 \mathrm{ml} /$ minute. Samples were analyzed at a wave length of $254 \mathrm{~nm}$ with a uv detector. The FT-IR spectrum was recorded on a Brucker-model tenser 27. NMR spectra $\left({ }^{13} \mathrm{c}\right.$ and $\left.{ }^{1} \mathrm{H}\right)$ on Brucker machine using $\mathrm{CDCl}_{3}$. The spectral data of FT-IR and NMR $\left({ }^{1} \mathrm{H}\right)$ of authentic compound was taken for confirmation of the isolated compound.

\subsection{Discussion and Summary}

\subsubsection{Solid state $N$-Methyl formamide}

The isolated white crystalline solid state substance N-Methylfomamide is confirmed.(Joshua et al.,1954B., J. M. Adams, 1979., Salah Nasr and Louis Bosio.,1998., J.Perepetuo et al.,1999., Hitoshi Ohtaki et al.,2000.,S.Lenza and W.L.Vasconcelos.,2001., R.F. R.K.Khanna et al.,2002., Bulent Caglar et.,al.,2010., Ayesha Jacobs et al.,2011.,Sivaraman., et al.,2012G., F.Hammami et al.,2015.,

\subsubsection{FTIR Analysis}

Our results of isolated N-Methyl formamide FTIR are in coincidence with that of Alstair J.Lees and Brian P.Straughan,1979 .,F.Fillaux and M.H.Baron.,1981., Richard R.Izac et al.,1982.,S.Aataka et al.,1984., S.V.Snorek et.al.,1989., Don Mc Naughton et.al.,1999., B.P.Kelleher et al.2002.,D.N.Sayhyanarayana and E.Ganeshsrinivas.,2003., Xiaofei Ma,Jiugao Yu.,2004.,J.R.Brucato et al.,2008, G.J.Branislav Jovic et al.,2010., Dugandzie,Vand E.Kahrovie.,2012., Zhen Yang et al.,2014., F.Hammami et al.,2015., and confirmed.

$\mathrm{N}$-methyl formamide (also known as monomethyl formamide) is a clear, colorless liquid with a slight amine odor (Clagett-carr et al., 1988). Finar (1995) reported that except formamide, which is liquid, all the amides are colorless crystalline solids, and those of low molecular weight are soluble in water. In the present investigation, the isolated compound was colorless crystal dissolved in water.

The N-methyl formamide proved to be capable of enhancing the cytotoxic potential of antitumoral compounds, both invitro and invivo. In many cases, thin ability depended on the sequence of treatment, and the enhancement of the cytotoxic effect occurred only when $\mathrm{N}$-methyl formamide administration succeeded anticancer drug treatment (Calcabrini et al., 1997; Valenti et al; 1997). It shows various types of bioactivities such as cytotoxis (Kroger et al; 1983), carcinogenic (Cob et al; 200), hepatotoxicity (Hyland et al; 1992) etc., N-methyl formamide with adriamycin on human melanoma cell line recorded a decrease of adriamycin- induced cytotoxicity and intracellular adriamycin content (Arancia et al; 1944).

In the present investigation, compound isolated in the extract in 1:1 (v/v) chloroform: methanol of red alga portieria hornmannii was probably identified as $\mathrm{N}$-methyl formamide based on the spectral data exhibited antibacterial activity. IR data of the isolated compound showed a peak at $342 \mathrm{~cm}^{-1}$ indicates the presence of $\mathrm{N}-\mathrm{H}$ stretching and carbonyl group presence close to $-\mathrm{NH} 2$ group indicated by the peak formed at $1693 \mathrm{~cm}^{-1}(\mathrm{C}=\mathrm{O}$ stretching). The presence of aldehyde proton is confirmed by $\mathrm{C}-\mathrm{H}$ stretching band at 3100-2800 $\mathrm{cm}^{-1}$. Appearance of strong absorption between 3500 and $3200 \mathrm{~cm}-1$ indicated the presence of secondary amine

( $\mathrm{NH}$ ). ( $\mathrm{NH}$ ). This data is in confirmation with the IR data of reference sample. (Fig.1)

In the $1 \mathrm{H}$ NMR spectra there is no peak in the region of $\delta=7-8$, hence it shows the absence of proton belongs to benzene ring. The integral value of peak appeared in the $1 \mathrm{H}$ NMR spectrum is as $\delta 8.3=4.8$

$\sim 5$ corresponds to $1 \mathrm{H}, \delta 8.5=5.6 \sim 5$ corresponds to $1 \mathrm{H}$ and $\delta 2.3=13.1 \sim 15$ corresponds to $3 \mathrm{H}$. The prominent peak at $\delta=8.3$ shows the presence of aldehyde proton in the compound . (Fig.2)<smiles>CC=CC</smiles> 
Isolation of N- Methyl Formamide from Red Algae Portieria Hornemannii_(Lyngbye) P.Silva Active against Two Plant Pathogenic Bacteria

The broad peak at $\delta 5.8$ indicates presence of either alcohol or amine, corresponds to a single protein probably a single hydrogen bonded to nitrogen. A prominent peak appears at $\delta 2.3$ indicates the presence of three proton in a methyl group<smiles>CC</smiles>

and there is no other pronounceable peak present in the ${ }^{1} \mathrm{H}$ NMR peak appears at $\delta 44.29$ and $\delta 49.09$ ppm for $\mathrm{NCH}_{2}$ of N-methylformamide. (Fig.3)This data is in confirmation with the findings of Kelleher et al. (2002).From the data of HPLC, IR and NMR $\left({ }^{1} \mathrm{H}\right.$ and $\left.{ }^{13} \mathrm{C}\right)$, isolated colorless crystalline compound was identified as $\mathrm{N}$-methyl formamide. The molecular formula for $\mathrm{N}$-methyl formamide: $\mathrm{C}_{2} \mathrm{H}_{5} \mathrm{NO}$ Molecular structure of N-methyl formamide

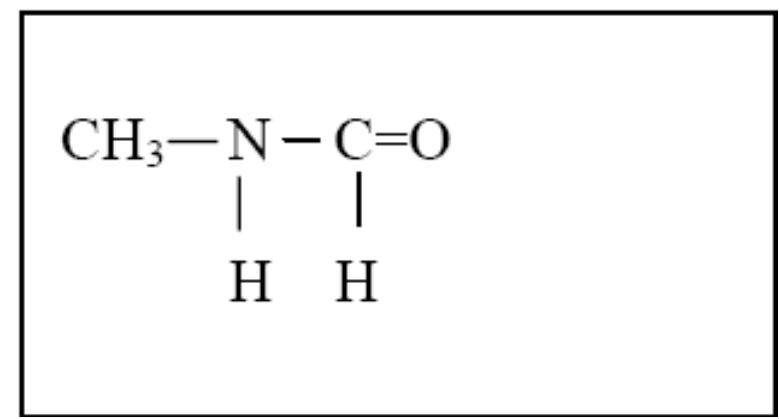

The plate shows the colorless crystal isolated in the extract of 1:1(v/v) chloroform: methanol of red alga Portieria hornemannii

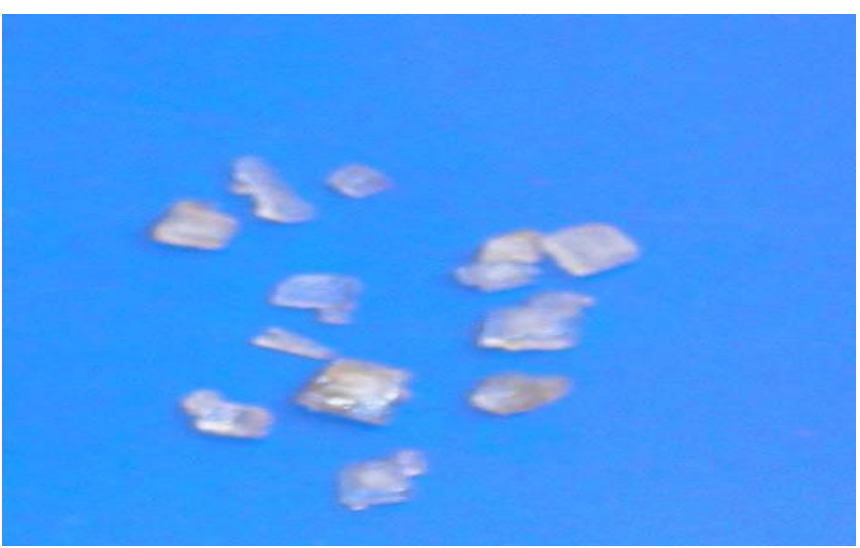

\section{Conclusion}

It is concluded that a colorless crystal compound isolated from 1: $1(\mathrm{v} / \mathrm{v})$ chloroform:methanol extract of red alga Portieria hornemannii showing promising source of bioactive compounds to control the plant pathogenic bacteria such as Xanthomonas axonopodis pv.citri and X.campestris pv. malvacearum causing cancer in citrus and angular spot in cotton, respectively.

Table1. FTIR, ${ }^{1} \mathrm{H}$ and ${ }^{13} \mathrm{C}$ NMR Spectroscopic data of the N-methyl formamide compound from Portiera hornemannii.

\begin{tabular}{|l|l|l|l|}
\hline$\delta \mathrm{H}$ & $\delta \mathrm{C}$ & FTIR $\mathrm{cm}^{-1}$ & Functional group \\
\hline 8.39 & 174 & 2854 & $\mathrm{C}-\mathrm{H}$ \\
\hline 5.87 & 51 & 3423 & $\mathrm{~N}-\mathrm{H}$ \\
\hline 2.3 & 29 & 2921 & $\mathrm{~N}-\mathrm{CH}_{3}$ \\
\hline & & 1634 & $\mathrm{C}=\mathrm{O}$ \\
\hline
\end{tabular}




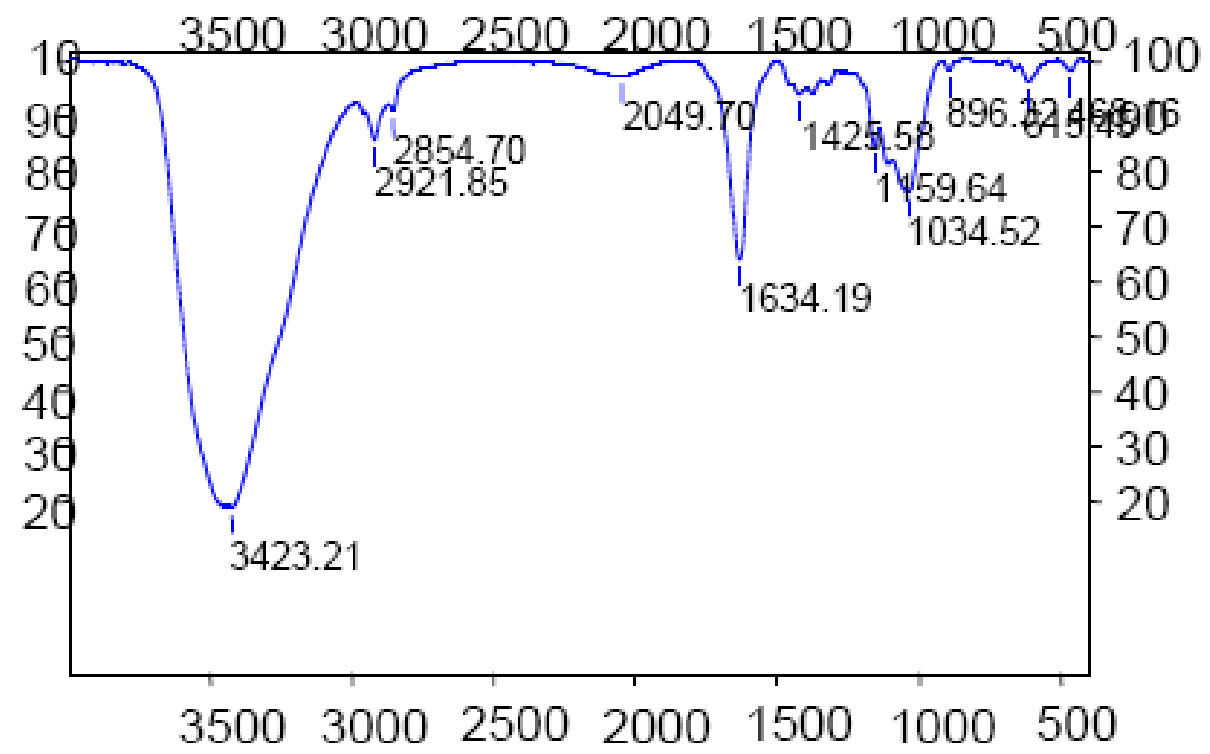

Fig1. FT IR data for the N-methyl formamide compound from red algae Portieria

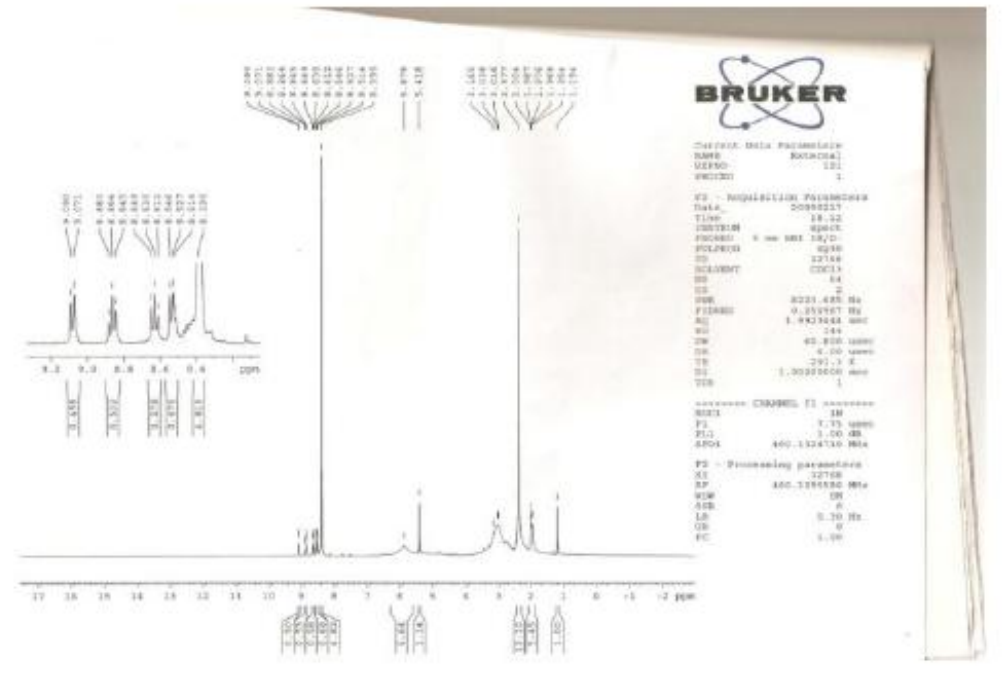

Fig2. H NMR of the isolated N-Methyl formamide from red algae Portieria hornemannii.

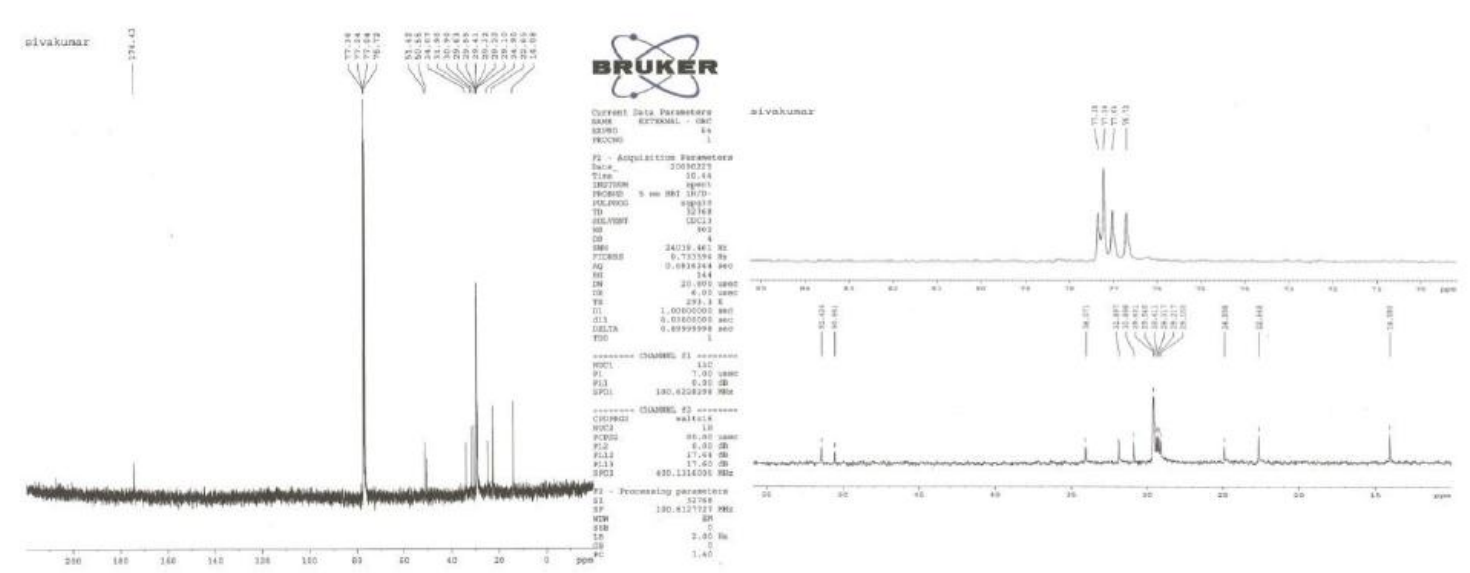

Fig3. ${ }^{3}$ C NMR of the isolated N-Methyl formamide from red algae Portieria hornemannii 


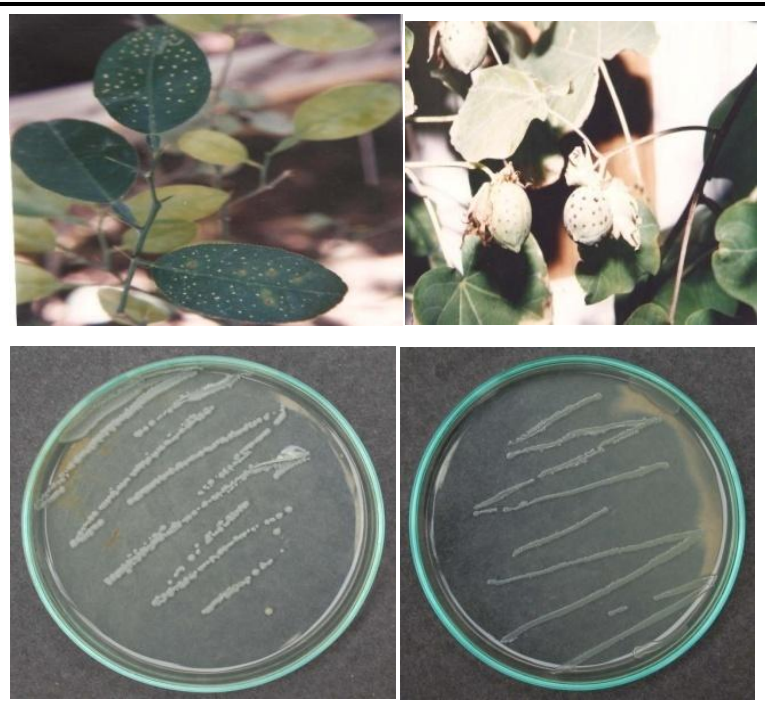

Fig4. The plate shows the growth of Xanthomonas axonopodies pv citri (a) and Xanthomonas campestris pv. malvacearum(b) on peptone sucrose agar medium and artificially developed canker on citrus(c) and artificially infected cotton plant $(d)$.

Table2. Isolated crystalline compound and Standard antibiotic Zone of inhibition against two plant pathogens.

\begin{tabular}{|l|l|l|l|}
\hline S.No & Concentrations & X.cam.pv.citri & X.cam.pv.malvacearum \\
\cline { 3 - 4 } & & Zone of inhibition in $\mathrm{mm}$ & Zone of inhibition in $\mathrm{mm}$ \\
\hline 1 & $50 \mu \mathrm{g} / \mathrm{ml}$ of N-Methyl formamide & $14.3 \pm 0.56$ & $15.5 \pm 0.25$ \\
\hline 2 & $100 \mu \mathrm{g} / \mathrm{ml}$ of Streptomycin sulphate & $37.6 \pm 0.56$ & $37.6 \pm 0.56$ \\
\hline
\end{tabular}

\section{ACKNOWLEDGEMENT}

I would be thankful to my family members and my dear friend Dr. V.Arul (Canada) who helped me for taking FTIR data.

\section{REFERENCES}

[1] Alistair J.Lees and Brain P.Straughan.1979.An NMR and IR study of ion-formamide interactions.J.of Molecular structure.Vol:54:37-47.

[2] Ara, J., V.Sultana. Ehteshamul Haque, S.A.Qureshi and V.V.Ahmed 1998. Bioactivity of seaweeds against Soilborne plant pathogens. Phylogia. 85: 292-299.

[3] Ara, J., V.Sultana, S.Ehteshamul-Haque, R.Qasim and V.V. Ahamad. 1999. Cytoxic activity of marine macro - algae on Artemia salina. Phytother. Res. 13: 304-307.

[4] Ara, J. V. sultana., R. Qasim and Viquer Uddin Ahmed. 2002a. Hypolipidamic activity of seawed from Karachi coast. Phytother.Res. F6. 479-483.

[5] Ara, J.V. Sultana, S.Ehteshamul-Haqye, M.Athar and R.Qasim. 2002b. Antibacterial activity of marine macro-algac from Karachi coast. Bull.Polish Academy Science . 50: 199-206.

[6] Abetz, P. and C.L.Young. 1983. The effect of seaweed extract spray derived from Ascophyllum nodosum on lettuce and cauliflower crops. Bot. Mar.26: 487-498.

[7] Arancia G., A.Molinari , A.Calcabrini , G. Citro, A.M .Villa , A.Verdina and G. Zupi.1994. Effects of sequential combinations of $\mathrm{N}$-methylformamide with adriamycin on cultured melanoma cells (M14). Exp. Mol.Pathol. Feb:60(1): 12-26.

[8] Arunkumar, K., and R.Rengasamy. 200a. Evaluation of antibacterial potential of seaweeds occurring along the coast of TamilNadu, India against the plant pathogenic bacterium Xanthomonas Oryzae pv. Oryzae (Ishiyama) Dye.Bot. Mar.43: 409- 415.

[9] Arunkumar, K., and R.Rengasamy. 200b. Antibacterial activities of seaweed extracts/ fractions obtained through a TLC profile against the phytopathogenic bacteria Xanthomonas oryzae pv. Oryzae. Bot. Mar. 43: 417-421. 
[10] Arunkumar, K.,N.Selvapalam and R.Rengasamy. 2005. The antibacterial compound sulphoglycerolipid 1-0 palmitoyl-3-0(6'-sulpho- $\alpha$ quinovopyranosyl)-glycerol from sargassum wightii Greville (Phaeophyceae). Bot.Mar.40: 441-445.

[11] Ataka, S., H.Takeuchi and M.Tasumi.1984.Infrared studies of the less stable cis form of Nmethylformamide and N-Methylacetamide in low -temperature nitrogen matrics and vibrational analysis of the Trans and CIS forms of these molecules.Journal of Molecular Structure.Vol.113:147-160.

[12] Ayesha Jacobs,Luigi R.Nassimbeni,Nothemba Silwana,nikoletta B.Bathori and Edwin Wrber.2011.Inclusion of 1,4-bis(diphenklhydroxymethyl)benzene with amides:structure and selectivity.CrystEngComm,Vol.13:7014-7018.

[13] Branislav Jovic,Aleksandar Nikolic,Erna Davidovic and Slobodan Petrovic.2010.N-H....O hydrogen bonding.An FT-IR,NIR study of N-methylformamide-ether systems. J.Serb.Chem.Soc. Vol.75(2):Vol.157-163.

[14] Brucato, J.R.,G.A.Baratta and G.Strazzulla.2006.An IR study of pure and ion irradiated frozen formamide.Astronomy and Astrophysics manuscript no.5095:1-7.

[15] Bulent Caglar,Beytullah Afsin,Erdal Eren,Ahmet Tabak,Cagri Cirak and Osman Cubuk.2010.The spectral structure and thermal characterizations of Dimethyl Sulphoxide, Pyridine, Ethanolamine and N-methyl Formamide intercalated Kaolinites. Z.Naturforsch. 65a,1009-1019.

[16] Calcabrini, A., A.M .Villa, A.Molinari , S.M.Doglia , and G.Arancia. 1997. Influence of Nmethylformamide on the intracellular transport of doxorubicin. Eur. J .Cell Biol.Jan.. 72(1): 61-9

[17] Clagett-Carr, K., G.Sarosy, J.Plowman, D.F.Hoth and B.Leyland-Jone. 1988. Nmethylformamide: cytotoxic, radiosensitizer, or chemosensitizer. Journal of Clinical Oncology, Vol. 6,906-918.

[18] Cobb ,W.,R. Arthur, E. Bogden, S. D. Reich, T. W. Griffin, D E. Kelton and.J. LePage. 2004. Activity of two phase I drugs N-methylformamide (NSC-3051) and Echinomycin (NSC-526417) against fresh surgical explants of human tumors in the 6-day subrenal capsule (SRC) assay. Investigational New Drugs .March. Vol.1(1): 93-94.

[19] Dugandzie,V and E.Kahrovie.2012.Synthesis and characterization of novel Chloro-Ru(III) complex with Formamide. Bulletin of the chemists and Technologists of Bosnia and Herzegovina.Vol.39:21-23.

[20] Don Mc Naughton,CoreyJ.Evans,Samantha Lane and Calus J.Nielsen.199.The high - resolution FTIR Far - Infrared spectrum of Formamide. Journal of Molecular Spectroscopy.Vol.193:104117.

[21] Fenical, W. 1997. New pharmaceuticals from marine organisms. Trends in Biotechnology 15, 339-341

[22] Finar,I.L.1995.Organic Chemistry.Vol. The Fundamental Principles. Longman Singapore Publishers (Pte)Ltd, Printed in Singapore.262-263.

[23] Fillaux, F. and M.H.Baron.1981.Vibrational spectra and dynamics of conformation and hydrogen bonding of $\mathrm{N}$-methylacetamide. IConfoemational dynamics of $\mathrm{CH} 3 \mathrm{CONHCH} 3$ molecule and NH out of plane band splitting. Chemical Physics.Vol.62:275-285.

[24] Hammami, F.,H.Ghalla,A.Chebaane and S.Nasar.2015.Structural and spectroscopic investigation of the N-methylformamide-water(NMF...3H20 complex. Molecular Physics: An International journals at the interface between chemistry and physics,Vol.113:2,149-159.

[25] Hitoshi Ohtaki,naoki Katayamma,Kazuhiko Ozutsumi and Tamas Radnai.2000.The structure of Liquid Formamide studied by means of X-Ray Diffraction and NMR at High temperature and high pressures.Journal of Molecular Liquids, Vol.88:109-120.

[26] Hyland,R.,A.Gescher.,K.C.Thummel, P.Schiller., K.Jheeta., A.W.Mynett., A.Smith and J. Mraz. 1992. Metabolic oxidation and toxification of N-methylformamide catalyzed by the cytochrome P450 isoenzyme CYP2E1. American Society for Pharmacology and Experimental Therapeutics. Volume 41, (2) pp. 259-266.

[27] Joshua Ladell and Benjamin Post.1954. The crystal structure of Formamide. Acta Cryst. Vol.7:559-564. 
Isolation of N- Methyl Formamide from Red Algae Portieria Hornemannii_(Lyngbye) P.Silva Active against Two Plant Pathogenic Bacteria

[28] Khanna, R.K.,M.S.Lowenthal,H.L.Ammon and M.H.Moore.2002.Molecular struc ture and infrared spectrum of solid amino formate $(\mathrm{HCO} 2 \mathrm{NH} 2)$ :Relevance to interstellar ices.The Astrophysical Journal Supplement Series, Vol.140:457-464.

[29] Kröger, H., R. Grätz and H. Grahn .1983.Influence of N-methylformamide on the development, the NAD synthesis, and the activity of the ADPR transferase of rat embryos. Biomedical and Life Sciences. January, Volume 39, (1), 93-94.

[30] Kelleher, B.P.,D.Sutton and T.F.O'Dwyer.2002.The effect of Kaolinite Intercalation on the structural arrangements of N-Methylformamide and 1.methyl-2-pyeeolidone.Vol.255:219-224.

[31] Kumar,C.S., Dronamraju.V, L.Sarada and R.Rengasamy.2008: Seaweed extracts control the leaf spot disease of the medicinal plant Gymnema sylvestre.Indian Journal of science and Technology:Vol.1.(3)Auguest., Volume 39, (1), 93-94.

[32] Kulik, M. M .1995. The potential for using Cyanobacteria (blue - green alge) and algae in the biological control of plant pathogenic bacteria and fungi. European J. Plant Pathology .101:585599.

[33] Lenza, R.F.S. and W.L.Vasconcelos.2001.Structural evolution of Silica sols modified with Formamide.Materials Research.Vol.4,No.3:175-179.

[34] Perpetuo, G.J., J.Buschmann,P.Luger,D.Lentz and D.Dreissig.1999.Low -temperature crystallization andf structure determination of $\mathrm{N}$-(trifluoromethyl) formamide, $\mathrm{N}-(2,2,2-$ trifluoroethyl) formamide and 2,2,2-trifluoroethyl isocyanide.Acta Cryst.B55:\&0-77.

[35] Richard R.Izac,Donald B.Stierle and James J.Sims.1982.Phytochemistry.Vol.21.No.1 229

[36] Salah Nasar and Louis Bosio.1998.X-ray scattering study of amorphous formamide. The Journal of Chemical Physics,Vol.108,No.6:2296-2301.

[37] Sathyanarayana, D.N. and E.Ganeshsrinivas.2003.Stimulation of the infrared spectra of Nmethylformamide and $\mathrm{N}$-methylacetamide by the extended molecular mechanics method.Indian Journal of Chemistry.Vol.41A:1564-1574.

[38] Schaad, N.W., Jeffrey Bryant Jones and Wesley Chun.1988.Laboratory Guide for Identification of Plant Pathogenic Bacteria. APSPress,ISBN0890542635,9780890542637.01-Jan-2001 Science -373

[39] Snorek, S.V.,B.A.Olsen and D.A.Pierson.1989.Liquid chromatographic determination of low molecular - weight amides in pharmaceutical matrics.Journal of chromatography.Vol.458:287293.

[40] Sivaraman, B., B.N.Raja Sekhar,B.G.Nair,V.Hatode,N.J.Mason.2013.Infrared spectrum of formamide in solid phase. Spectrochimica Acta part A:Molecular and Biomolecular Spectroscopy, Vol.105:238-244.

[41] Valenti, A.M., A .Niero., G. Monti , F. Marangolo., M. Marangolo and Paclitaxel.1997.Nmethylformamide: in vitro interactions in human colon cancer cell line. Anticancer Res. Jul-Aug; 17(4A):2491-7.

[42] Xiaofei Ma and Jiugao Yu.2004.Fermamide as the plasticizer for Thermoplastic Starch. Vol.93:1769-1773.

[43] Zen Yang,Hao Lin,Tian Gui,Rong - Fei Zhou,Xiang - Shu Chen.2014.Infrared spectroscopy of N-Methylacetamide in water from high - level QM/MM calculations. Chines Chemical Letters.Vol.25:107-110. 


\section{AUTHORS' BIOGRAPHY}

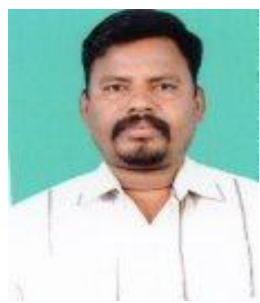

Dr.S.R.Sivakumar, MSc.,M.Phil.,Ph.D., currently working as Assistant Professor in the Department of Plant Science,Bharathidasan University,Trichy-24 from 2612-2012 to till date. I did Ph.D in Government Arts college,Ariyalur under affiliation to Bharathidasan University and also worked as Guest Lecturer for 7 years.Currently I am working on bioactive compound isolation, characterization from seaweeds and plants, against plant and human pathogens (invitro and invivo study) and guided 10 MSc., Biotechnology Students,Guidng 6 Ph.D and 1 M.Phil.,student under my research supervision. At Present I am handling classes for MSc.,(Botany).,MSc.,Life Science(5 Year Integrated Course)., M.Phil.,(Botany). Participated in various seminars, conferences, workshops (both National\&Internationals) related to Tissue culture, Biometabolites, IR,NMR,Xrd techniques, Nanotechnology,Microbiology, Taxonomy and Molecular biology.

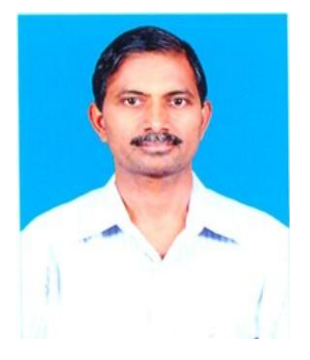

\section{S .Radhakrishnan}

Experience:Analytical spectroscopic instrumental techniques More than 25 years experience in teaching and $R \& D$.

Projects: Member in 3 projects

Papers: 21 Papers in peer reviewed international journals.

Invited talks: Given many lectures in national conferences, educational institution

Teaching: Handling instrumentation related papers for B.Tech students.

Committee member: Served as member in many institutional committees.

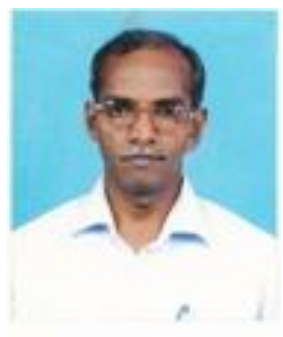

Dr.K.Kulangiappar, obtained Ph.D degree from Alagappa University, Karaikudi in 2010. He has experience in synthesizing organic fine chemicals \& isolating the active principles from plant materials. He worked as chemist (1983-1998) in M/S Bio-Organic, Chennai, \& M/S Vipaux (India) Pvt Ltd, Gumidipoondi. Having these experience he joined in Central Drug Research Institute (CDRI), Lucknow in process development division. After six years service in CDRI, he moved to Central Electrochemical research Institute, Karaikudi, in electro organic division as senior Technical Officer. At present he is synthesizing organic fine chemicals and drug intermediates by electrolysis. 